Pamukkale Üniversitesi

İlahiyat Fakültesi Dergisi

Mart/2016, Y11:3, Sayı:5, s. 71-87

\title{
DEDE ÖMER-İ RÛŞENÎ DÎVÂNINDA GÜZELLİK UNSURU OLARAK “BOY” VE TASAVVUFÎ ÇAĞRIŞIMLARI
}

Nesibe Kablander*

\begin{abstract}
Özet
Klâsik edebiyatta sevgiliye ait unsurlar doğrudan ifade edilmeleri yanında çeşitli benzetmelerle de eserlere konu olurlar. Dîvân şiirinde görülen mâşuka ait unsurlar ve bunlara dair benzetmeler esasen birer remiz olup arkalarında dinî veya dünyevî anlamlar gizlidir. 15. yüzyılın önemli şâirlerinden olan Dede Ömer-i Rûşenî (ö.892/1487) mutasavvıf bir şâir olmakla birlikte tasavvuf yoluna intisab etmeden önce yazdığı âşıâne gazallerle de kendisini devrinin edebiyat âlemine kabul ettirmiş bir isimdir. Dolayısıyla onun şiirlerini yorumlarken dinî ve tasavvufî̀ olduğu doğrudan belli olanlar dışında dinî ve dünyevî anlamları birlikte düşünmek yararlı olacaktır. Bu çalışmada, yukarıda zikredilen hususlara dikkat edilerek sevgilinin güzellik unsurlarından biri olan “boy”un Dede Ömer-i Rûşenî Dîvân'ında kullanılışına dâir örnekler sunulmuş, bilhassa bunların tasavvufî çağrışımlarına işaret edilerek bazı değerlendirmeler yapılmıştır.
\end{abstract}

Anahtar Kelimeler: Rûşenî, Dîvân, tasavvuf, boy, vahdet.

\section{Stature As the Element of Beauty in the Dīwān of Dede Ömer-i Rūşenī and Its Sufistic Connotations}

\begin{abstract}
Factors of related with beloved are described with the direct expression and also the various metaphors in classic literature. Substantially, seen in the Dīwān poetry factors of related with beloved and metaphors about them are sign and religious and secular meanings are hidden behind them. Dede Ömer-i Rūşen̄̄ who important poets in $15^{\text {th }}$ century is sūfì poet, before joining the sūfĩ order wrote non-religiouse poems. With that poems he has been accepted to world of literature. When interpreting his poems, other than known to be sufistic poems, would be useful to think together religious and secular meanings. In this study, about the stature that one of the beauty elements of beloved have been explained with examples from Dede Ömer-i Rūşeni's Dīwān and some assessments have been made especially with reference to their sufistic connotations.
\end{abstract}

Keywords: Rūşen̄̄ order, Dīwān, sufism, stature, unity.

\footnotetext{
*Arş.Gör., Pamukkale Üniversitesi İlahiyat Fakültesi, nesibe_yagmur26@ hotmail.com
} 


\section{Giriş}

Dîvân şiirinde sevgili, üstün niteliklerle donatılmış olup ideal bir tipi sembolize ettiğinden âşık gibi hâlden hâle girip değişmez. Bununla birlikte âşığın çeşitli hâllerinin müsebbibi olduğu için şiirin merkezinde o vardır ve ona âit unsurlar açık veya kapalı olarak şiire rûhunu veren anlamları ihtivâ ederler.

Mazmun denilen ve zımnında asıl kastedilen anlamı barındıran kelimelerin kullanılışı, şâirlerin başarısının da bir göstergesidir. 15. yüzyılın önemli mutasavvıf şâirlerinden Dede Ömer-i Rûşenî’nin şiirleri, mutasavvıf şâirlerin çoğunun şiirlerinden farklı olarak sadece bir mesaj iletmez, edebî zevk de verir. Bunda yaratılıştan gelen şâirlik yeteneğinin payı olduğu söylenebilir. Henüz yaşadığı dönemde adını şiir meclislerinde kabul ettirmiş ve şiirlerine nazîreler yazılmış bir isim olması, tabiatında var olan bu yeteneği göstermektedir.

Dîvân şiirinde sevgiliye ait pek çok unsur kullanılmış olmakla birlikte bu çalışmada Dede Ömer-i Rûşenî Dîvânı esas alınarak “boy”a odaklanılmış, “boy”un ifâde ettiği anlamlar ve "boy”la ilgili benzetmeler ele alınmıştır. Çalışmaya konu olan beyitler dîvânda yer alan ilk kasîde ve gazellerinin tamamındaki ilgili beyitler olup dîvândaki diğer şiirler bu çalışmanın dışında tutulmuştur.

Dîvân edebiyatında boy, vahdeti sembolize eder. Şiir dünyevî-âşıkâne hislerle yazılmış olsa bile bu mazmunun arka planında vahdet ve onu ifâde eden Allah vardır. Fakat bir şâirin şiirleri yorumlanırken temeldeki anlam verilmekle birlikte elbette şâirin temsil ettiği dünya görüşü de dikkate alınmalıdır. Bu çalışmada, tasavvufa intisâb etmeden önce de şiirler yazmış olan Rûşenî’nin şiirleri değerlendirirken söz konusu husûsa dikkat edilmiştir.

\section{Dede Ömer-i Rûşenî’nin Hayâtı ve Eserleri}

\section{1. Hayâtı}

Dede Ömer-i Rûşenî, o dönemde Aydın-ili olarak anılan ve İzmir'i de içine alan bölgenin önemli yerleşim merkezlerinden olan Güzelhisar'a bağlı Tire'de doğmuştur. Doğum tarihi tam tesbît edilememiştir; fakat tarihi verilere dayanarak 1407-1417 yılları arasında doğduğu tahmin edilmektedir. Şâirin Rûşenî mahlasını benimsemesinin sebebi 
memleketi olan Aydın-ili'yle mânâ yakınlığıdır. ${ }^{1}$ Yetişmesinde ve tasavvufa intisâbında önemli bir etkisi bulunan ve Molla-i Rûmî olarak tanınan ağabeyi Alâeddin Ali (ö. 867/1462-1463), ${ }^{2}$ Anadolu'daki ilk Halvetî şeyhlerindendir. Bundan dolayı Rûşenî’nin ilmî ve tasavvufî̀ yönden tanınmış bir âile çevresinde yetiştiği söylenebilir. ${ }^{3}$

Rûşenî’nin hayatı kronolojik olarak üç devreye ayrılabilir: ${ }^{4}$

1. Aydın ve Bursa Yılları

Şâirin Aydın yıllarıyla ilgili bilgiler oldukça mahduttur. Kaynaklardaki bilgilerden tahsil hayatına burada başladığı ve gençlik döneminde Bursa'ya geçerek medrese tahsilini burada yaptığı anlaşılmaktadır. Yine kaynaklardan anlaşılan, eğitiminin bir döneminde de İstanbul'da bulunduğudur. ${ }^{5}$ Onun bu devrelerde yazdığı melâhî ve dünyevî zevkleri ifâde eden şiirlerinin daha o dönemde edebî çevrelerde beğenildiği ve kendisinin bir şâir olarak kabul gördüğü bilgisi de kaynaklarda mevcuttur. ${ }^{6}$ Bursa' da yaşadığ 1 birtakım huzursuzluklar sonucu bunalan Rûşenî, günümüzde Karaman olarak bildiğimiz Lârende'de bulunan ağabeyi Alâeddin Ali'nin yanına giderek tasavvufa intisâb etmiştir. Daha sonra da Bakü’ye giderek devrin büyük mutasavvıflarından, Halvetiyye tarîkatının pîr-i sânîsi kabul edilen Seyyid Yahyâ-yı Şirvânî’ye (ö. 868/1463-64) intisâb etmiştir. ${ }^{7}$

2. Bakü, Karabağ, Gence, Berde y1lları

Sülûkunu kısa sürede tamamlayan Rûşenî, Şirvânî'nin halîfesi olmuş ve Anadolu'da irşadla görevlendirilmiştir. Fakat mürşidinden ayrı kalmak istemediği için onun rızâsını alarak Karabağ, Gence, Berde gibi civar bölgelerde irşâdına devam etmiştir. Buralarda bir yandan Sünnîliğin yayılmasına hizmet eden bir şeyh olarak görev yaparken bir yandan da artık dînî-didaktik mâhiyette bulunan şiirler yazmış, şeyhinin

\footnotetext{
${ }^{1}$ Bkz., Âzâde Mûsâbeyli, Dede Ömer Rûşenî ve Külliyâtt, Kafkaz Üniversitesi, Kafkaz Araştırmaları Enstitüsü, 2014, s.30-32; Mustafa Uzun, "Dede Ömer Rûşenî", Türkiye Diyanet Vakfi İslâm Ansiklopedisi (DïA), IX, 81.

${ }^{2}$ Nurten Altuntop, Dede Ömer Rûşenî’nin Dîvânı'nda Tasavvuf (yayımlanmamış yüksek lisans tezi), Hitit Üniversitesi Sosyal Bilimler Enstitüsü, Çorum 2015, s. 16.

${ }^{3}$ Uzun, "Dede Ömer Rûşenî", DİA, IX, 81.

${ }^{4}$ Mûsâbeyli, Dede Ömer Rûşenî ve Külliyâtı, s. 32.

${ }^{5}$ Detaylı bilgi için bkz. Uzun, "Dede Ömer Rûşen̂̂”, DİA, IX, 81; Ayrıca bkz., Münire Kevser Baş, "RÛŞENÎ, Dede Ömer", Türk Edebiyat1 İsimler Sözlüğü, http://www.turkedebiyatiisimlersozlugu.com/index.php?sayfa=detay\&detay=6302, E.T: 04. 11. 2015.

${ }^{6}$ Uzun, "Dede Ömer Rûșenî", DİA, C. 9, s. 81.

${ }^{7}$ Rûşenî’nin bu devredeki hayatıyla ilgili detaylı bilgi için bkz. Mûsâbeyli, Dede Ömer R̂uşenî ve Külliyâtı, s. 34-36.
} 
vefâtından sonra da tarîkatın şeyhi olmuştur. Akkayunlu hükümdârı Uzun Hasan'ın, daha sonra Rûşenî’nin Tebriz'deki en meşhur talebelerinden olan İbrâhim Gülşen̂̂’yi göndererek kendisini Tebriz'e davet etmesi üzerine, Rûşenî davete icabet ederek Tebriz'e gitmiştir. ${ }^{8}$

\section{Tebriz Y1lları}

Tebriz'de sultanın hanımı Selçuk Hâtun tarafından yaptırılan tekkeye yerleşen Rûşenî, ömrünün geri kalanını burada geçirmiştir.

Tebriz yılları Rûşenî’nin tasavvufî̀ ve edebî şöhretinin zirveye çıktığı dönemdir. Bunda Akkoyunlu hükümdârlarının âlim ve sanatkârları himâye etmelerinin de rolü vardır. Böyle bir ortamda irşâdına devam eden ve talebeler yetiştiren Rûşenî, tasavvufî mesnevîlerini burada kaleme almış ve yazdığı şiirler İstanbul'a kadar ulaşarak şiirlerine nazîreler yazılmıştır. ${ }^{9}$ 1487'de Tebriz'de vefat eden Rûşenî, tekkesinin hazîresindeki türbeye defnedilmiştir.

\section{2. Eserleri}

\section{A. Mesnevîler:}

1. Çoban-nâme: Mevlânâ'nın Mesnevî'sindeki "Mûsâ ile Çoban” adlı kıssanın genişçe tercümesidir. 25 bölümden oluşan eser yaklaşık 1000 beyittir. Mesnevîleri içinde en erken kaleme alınan bu eser olup H. 880/M. 1475-76' da tamamlanmıştır. ${ }^{10}$

2. Miskinlik-nâme: 1484'te tamamlanan eser, Miskin-nâme diye de anılan didaktik bir manzûmedir. Mesnevîleri içinde tamamiyle te'lif bir eser olması ve tasavvufî görüşlerini ortaya koymasıyla bilhassa önemlidir. 128 beyitlik bir girişten sonra 34 bölümden oluşur. Bu bölümlerde Hz. Peygamber ve ashabının başından geçen ibret verici olaylar, evliyâ menkabeleri ve çeşitli hikâyeler tasavvufî yorumlarla anlatılmıştır. $^{11}$

\footnotetext{
${ }^{8}$ Mûsâbeyli, Dede Ömer Rûşenî ve Külliyâtt, s. 36; Uzun, "Dede Ömer Rûşen̂̂”, DİA, IX, s. 81.

${ }^{9}$ Rûșenî’nin Tebriz yıllarıyla ilgili ayrıntılı bilgi için bkz. Mûsâbeyli, Dede Ömer Rûşenî ve Külliyâtt, s. $37-41$.

${ }^{10}$ Uzun, "Dede Ömer Rûşenî”, DİA, IX, 82.

${ }^{11}$ Uzun, "Dede Ömer Rûşen̂̂”, DİA, IX, 82. Bu mesnevî üzerinde Uzun'un doktora çalışması mevcuttur: Mustafa Uzun, Dede Ömer Rûşenî: Hayâtı, Eserleri ve "Miskinnâme" Mesnevîsi (Edisyon kritik), Doktora Tezi, Marmara Üniversitesi Sosyal Bilimler Enstitüsü 1982.
} 
3. Ney-nâme: Konusunu Mevlânâ'nın Mesnevî'sinin ilk 18 beytinden alan eser şerh mâhiyetinde olup 1028 beyittir. Hâtimesiyle birlikte 24 bölümdür. Bu eserin önemli bir özelliği, son kısmında doğum yeri ve âilesi hakkında birtakım bilgilerin bulunmasidir. $^{12}$

4. Kalem-nâme: Yaklaşık 250 beyit hacminde olup hâtimesi bulunmadığından tamamlanmamış izlenimi veren bir eserdir. İlk 100 beytinde kalemden bahsedilmekte, devamında ise tasavvufî yorumlarla bazı hikâyeler bulunmaktadır. ${ }^{13}$

\section{B. Dîvân:}

Türkiye'de ve yurtdışında birçok nüshası bulunan dîvânda, nüshalarda bazı küçük değişiklikler bulunmakla birlikte birkaç münâcaat, beş na't, beş tercî'-bend, dört terkîb-bend, doksan kadar gazel, yüzden fazla tuyuğ, rubâî ve beyit bulunmaktadır. ${ }^{14} \mathrm{Bu}$ çalışmada, bunlardan ilk kasidenin ilgili iki beyti dışında sadece gazeller kullanılmş, diğerleri incelemeye dahil edilmemiştir.

\section{Rûşenî Dîvân'ında Boy}

Tesbît Edilen Beyitler: ${ }^{15}$

Aşağıda yer alan iki beyit, dîvândaki ilk kasîdeden alınmıştır:

\section{1/5: ${ }^{16}$ Boyuñ serv-i hırâmândur semen-sâ kâkü̈lüñ sünbül}

\section{Hatuñ mânend-i reyhândur ruhuñ misl-i şakâyıkdur}

"Boyun salına salına (nazla) yürüyen bir servi, yâsemine benzeyen kâkülün (de) sümbül (gibi)dir. Ayva tüylerin reyhân benzeri, yanağın (ise) şakâyık gibidir.”

Klâsik edebiyattaki şiirlerin mazmun katmanının arka planında yer alan dinî ve tasavvufî unsurları göz ardı etmemek gerekir. "Boy”un ve boyun benzetildiği "serv"in

\footnotetext{
12 Uzun, "Dede Ömer Rûşen̂̂”, DİA, IX, 82.

13 Uzun, "Dede Ömer Rûşen̂̂", DİA, IX, 82.

14 Uzun, "Dede Ömer Rûşen̂̀”, DİA, IX, 82.

${ }^{15} \mathrm{Bu}$ incelemede kullanılan beyitlerin tesbîti için Semra Aydemir ve Orhan Kemâl Tavukçu'nun çalışmaları esas alınmıştır. Bkz. Semra Aydemir, Dede Ömer Rûşenî (Hayatı, Eserleri ve Dîvânının Tenkidli Metni), Yüksek Lisans Tezi, Selçuk Üniversitesi Sosyal Bilimler Enstitüsü, Konya, 1990; O. K. Tavukçu, Dede Ömer Rûşenî Hayatı, Eserleri, Edebî Kişiliği ve Dîvânının Tenkidli Metni, http://ekitap.kulturturizm.gov.tr/Eklenti/10601,dede-omer-rusenipdf.pdf?0 E.T: 07.04.1015. Beyitlerin açıklamalarındaki tasavvufî̀ yorumlar için ise Ali Nihat Tarlan'ın Fuzûlî Dîvânı Şerhi'nden istifade edilmiştir: A.N. Tarlan, Fuzûlî Dîvânı Şerhi, Akçağ Yayınları, Ankara 1998.

${ }^{16}$ Rakamların ilki dîvândaki kaçıncı kasîde/gazel olduğunu, ikincisi ise beyit numarasını ifade etmektedir. Yukarıdaki kasîdenin vezni mefâilün x 4’tür.
} 
tasavvufî anlamı "vahdet”tir. ${ }^{17}$ Bunların "1" rakamına benzeyen elif gibi olmaları, aralarında "vahdet"le münâsebet kurulmasına imkân sağlamıştır. ${ }^{18} \mathrm{Bu}$ kasîde Hz. Peygamber'e yazılmış olduğu için, yani bir na’t olması sebebiyle ondaki beyitleri zaten dinî ve tasavvufî bir değerlendirmeye tâbi tutmak icap eder. Dolayısıyla burada Allah'ın elçisi olan Hz. Peygamber, kulları "vahdet”e çağıran bir temsilci olarak vahdet kaynağıyla bağlantısı kurularak övülmüştür, diyebiliriz.

1/9: Senü̃̃ şî̂în tutaguña rutab ${ }^{19}$ dinse aceb midür

Bu nahlistân-ı âlemde ki boyuñ nahl-i bâsıdur

"Senin tatlı dudağına olgun (ve) tâze hurma (gibidir) dense şaşırtıcı mıdır? (Çünkü) hurma bahçesi (gibi olan) yeryüzünde senin boyun uzun bir hurma fidanına (benziyor)."

Nahlistan daha çok "hurma bahçesi”, nahl de "hurma fidanı" anlamında kullanılan bir ifade olduğu için günümüz Türkçesine çevirirken bu anlamları tercih ettik. Burada Peygamberimizin boyu uzun bir hurma fidanına benzetilmiştir. Bu da onun kemâline ve temsil ettiği dinin hakkâniyetine bir övgü olarak değerlendirilebilir.

Gazeller: $^{20}$

\section{2/5: ${ }^{21}$ Cây idüp itdi R̂̂şenî rûşen}

$$
\text { Cûy-l çeşmüñde bu sehî-bâla } \hat{a}^{22}
$$

"Rûşenî! (Bu) fidan gibi düzgün boylu (sevgili) senin gözünün 1rmağını yer edinip (senin varlığını) aydınlattı (görünür kıld1)."

$\mathrm{Bu}$ beyitte klâsik edebiyatta âşı̆̆ın ayrılmaz bir parçası olan gözyaşını görmekteyiz. "Sehî-bâlâ" ifadesiyle tek olan Allah'a, vahdete rahatlıkla gidilebilir. Mutasavvıf bir şâir için sevgili Allah’tır. O, hakikî sevgilidir. Bütün mecâzî sevgililer ve güzeller onun "cemâl" isminin tecellîsinden başka bir şey değillerdir. Allah aşkını tatmış bir kişi, ondan ayrı olmanın ve ona layık olamamanın ızdıraplarıyla sürekli gözyaşı döker. Gözyaşı, tasavvuftaki "çile” döneminde de önemli bir temizlenme ve

\footnotetext{
17 Bkz., Tarlan, Fuzûlî Dîvânı Şerhi, s. 37.

18 Bkz., Tarlan, Fuzûlî Dîvânı Şerhi, s. 127.

19 Bu kelime Tavukçu'nun çalışmasında "rateb" olarak kaydedilmiştir.

${ }^{20} \mathrm{Bu}$ kısımdan itibaren artık sadece gazellerdeki ilgili beyitler görülecektir.

21 Vezni: feilâtün/mefâilün/ feilün

${ }^{22}$ Bu ifâde Tavukçu'nun çalışmasında "sehî bâlâ" şeklinde tire kullanılmadan yazılmıştır.
} 
yükselme unsurudur. Sâlik, gözyaşlarıyla kendindeki mâsivâ kirlerini dışarı atar ve asıl kaynağına lâyık hâle gelip kâmil bir insan, "Allah dostu” mertebesine yükselir.

5/5: ${ }^{23}$ Her subh-dem çemende billâh hoş degül mi

Sen serv-kâmet ile el ${ }^{24}$ alışup salınmah

“Allah için (Allah aşkına bir düşün), her sabah vakti sen servi boylu (sevgiliyle) el ele tutuşup nazlı nazlı yürümek hoş değil mi?"

Buradaki "subh-dem" ifadesine bilhassa dikkat çekmemiz gerekir. Sabah vakti tasavvufta önemlidir. Seherde uyanık olmaya, bu vakti zikir ve ibadetle geçirmeye dikkat edilir. ${ }^{25}$ Seherdeki serv-kâmet de bu vakte özel bir değer veren ve lutuflarını bolca gönderen Allah’ı ifade eden bir mazmun olarak kullanılmıştır. Allah'la râbıtasını sağlayan bir mürîdin, bir sâlikin dünyası feyizli ve aydınlıktır. ${ }^{26}$

6/1: ${ }^{27}$ Iy risâlet bûstânında hirâmân serv-kad

V'iy nübüvvet ravzasinda yâsemen-bû lâle-had

"Ey peygamberlik bağında salına salına (nazla) yürüyen servi boylu! Ve ey nübüvvet bahçesinde yasemin kokulu (ve) lâle yanaklı (olan sevgili)!”

$\mathrm{Bu}$ beyitten açıkça anlaşıldığı üzere Hz. Peygamber için yazılmıştır. Son ve en mükemmel din olan İslâm'ın temsilcisi olan Hz. Peygamber, peygamberlik bahçesinde, yani diğer peygamberlerin arasında en yüce ve onlara da imam olacak şekilde resmedilmiştir.

$9 / 5:^{28}$ Bu nahl-i nihâlinde olan ratb rutabdan ${ }^{29}$

Ehl-i nazaruñ cümlesi mertûb olacahdur

"Bu hurma fidanı (gibi olan boyunda) yetişen tâze hurmadan, bakmayı (ve görmeyi) bilenlerin hepsi (istifâde edip) tâzelenecektir (gıdâlanarak gençleşecektir).

\footnotetext{
23 Vezni: müstef'ilün/feûlün/ müstef'ilün/feûlün

24 Tavukçu'nun çalışmasında "âl”" şeklindedir.

${ }^{25}$ Seher vaktinin önemine âyetlerde ve hadîs-i şerîflerde de işaret edilmiştir. Bazı örnekler için bkz. İbrahim Canan, Kütüb-i Sitte Muhtasarı Tercüme ve Şerhi, IX, Akçağ Yayınları, Ankara 1990, s. 302325.

26 "Seher”le ilgili bkz., Zafer Erginli vd., Metinlerle Tasavvuf Terimleri Sözlüğü, Kalem Yayınevi, İstanbul 2006, s. 881.

${ }^{27}$ Vezni: fâilâtünx3/fâilün

${ }^{28}$ Vezni: mef'ûlü/mefâîlüx2/feûlün

29 Tavukçu'nun çalışmasında "ratb-i rateb" şeklindedir.
} 
İslâm, hidâyet dînidir. Allah insanlara doğru yolu göstermiş ve dîninin âdetâ cisimleşmiş örneği olarak Hz. Peygamber’i göndermiştir. O, güzellikler mahşeri gibidir; fakat görüp istifade edebilmek için mânâ gözünden perdeyi kaldırmak icap eder. Bu beyti daha dar dairede düşünürsek bir mürid için mürşid-i kâmil de böyledir. Bakmayı bilen ve teslim olan bir mürid, mürşidinin elinde, onun yol göstermesiyle mânâ mertebelerini kateder ve insân-1 kâmil olmaya doğru ilerler.

\section{1/2: $:^{30}$ Kadd-i tûbâ-sâyeñi serve nice nisbet idem}

Serv bir bâd-ı hevâ-y-ile salınur çûbdur

“(Cennetteki) Tûbâ ağacının gölgesi(nin yansıması gibi olan) boyunu nası1 serviye benzetebilirim? (Zîrâ ona nisbetle) servi, boş yere sallanan (değeri olmayan) bir tahta parçası gibidir."

Sevgilinin boyu için genellikle bir benzetme unsuru olarak kullanılan servi, bu beyitte mukâyese unsuru olarak kullanılmış ve sevgilinin boyu yanında değerinin olmadığı ifade edilmiştir. Sevgilinin boyu, cennetteki ağaç olması itibariyle daha belirgin mânevî çağrışımları olan "Tûbâ ağacının gölgesi”ne teşbih edilmiştir.

12/5: ${ }^{31}$ Sen eyâ serv-i çemân ${ }^{32}$ itdükçe gül-geşt-i çemen

Dir gören bu serv-i nâzük nahl-i hoş nev-şâddur ${ }^{33}$

“Ey nazla salına salına yürüyen servi! Sen yeşillik(ler, çiçekler ve gül fidanlarıyla dolu bir bahçeye) gül seyrine çıktıkça seni gören(ler): 'Bu nârin servi, hoş (bir) fidan (ve) tâze bir mutluluktur (mutluluk sebebidir)' derler."

Bu beyti de İslâm diniyle Hz. Peygamber'in getirmiş olduğu tazeliğin bir ifadesi olarak değerlendirebiliriz. Gül tasavvufta kesrettir, servi ise vahdettir. ${ }^{34}$ Çeşitli şirk unsurları ve putlarla yaşayan bir milletin içinde tevhîde çağıran bir elçi olarak zuhûr eden Hz. Peygamber, insanlığın mutluluk ve kurtuluş vesilesi olmuştur.

\section{2/6: Sünbül-i müşgîüñ̈̈ñ sarmaşdugl bu kaddüñe}

Sünbülü̃̃ san sarmaşıkdur kâmetüñ şimşâddur

\footnotetext{
${ }^{30}$ Vezni: fâilâtünx3/fâilün

${ }^{31}$ Vezni: fâilâtünx3/fâilün

${ }^{32}$ Aydemir'in çalışmasında "serv-i cihân” şeklindedir.

${ }^{33}$ Aydemir'in çalışmasında "serv-i nâz-1 Helluh u Nevşâddur" şeklindedir.

${ }^{34}$ Bkz., Tarlan, Fuzûlî Dîvânı Şerhi, s. 47.
} 
"Misk kokulu zülfünün sarıldığı bu boyunda, saçının kıvrımı sanki sarmaşık, boyun (da) şimşir ağacıdır.”

$\mathrm{Bu}$ beyte biraz daha farklı bir açıdan yaklaşmak uygun olacaktır. Tasavvufta saç kesrettir. Boy vahdet olduğu halde vahdeti örten kesret unsurları, boyun şimşâd olarak görünmesine sebep olmuştur. Şimşâd da bir ağaç olmasına rağmen, servi gibi elif şeklinde dümdüz olmayıp dallı budaklı olduğundan kesretle birleşir. ${ }^{35}$ Kâinatta Allah'ın yarattı unsurlar, mâsivâ, insanı teshîr eder ve gözünü perdeleyip vahdeti görmeye bir engel oluşturur. Bütün varlıklar Allah'ın sanat eserleridir, fakat insan bunları asıl kabul edip sanatla sanatkârı karıştırırsa hata eder.

14/5: ${ }^{36}$ Şâh-ı rez ${ }^{37}$ kaddüñle rengîn leblerüñ gördüm didüm

Ne aceb şâh-ı inebde bitdügin unnâblar

"Asma dalı (gibi nârin) boyunla parlak renkli (hoş) dudaklarını gördüm (ve) ‘Üzüm dalında (üzüme benzeyen) çiğde yetişmesi neden garip olsun?' dedim.”

Rûşenî'nin tasavvufa intisâbından önce yazdığı şiirlerinin de var olduğunu yukarıda belirtilmişti. Bunların hangileri olduğunu tam olarak tesbît edemesek de açıkça dîni-tasavvufî bir iz göstermeyen şiirlere daha geniş bir bakış açısıyla yaklaşmak doğru olacaktır. 14 numaralı gazelin bu şekilde yorumlanmaya müsait olduğunu söyleyebiliriz. Dolayısıyla tasavvufî bir bakış açısıyla yorumlanabileceği gibi, lirik bir aşk şiiri olarak da değerlendirilebilir. Tasavvufî olarak boy ve leb vahdettir. Leb, fenâfillahı ifade etmesiyle bilinir. ${ }^{38}$ Fakat boyun üzerinde saç, hat gibi kesret unsurları bulunduğu gibi, dudak da kesreti ifade eden hatla çevrilidir. Ama buna şaşırmamak gerekir, çünkü insanın değeri, bu kesret unsurlarını aşıp vahdete ulaşmasıyla ortaya çıkacaktır.

Diğer taraftan burada dünyevî bir güzelin anlatıldığı da düşünülebilir. Şâir sevgilisinin boyunu ve dudaklarını yukarıdaki ifadelerle övmüştür. Gazelin diğer beyitlerinde de sevgiliye ait muhtelif unsurlar çeşitli teşbihlerle anlatılmakta ve övülmektedir.

\footnotetext{
${ }^{35}$ Tarlan, Fuzûlî Dîvânı Şerhi, s. 157.

36 Vezni: fâilâtünx3/fâilün

37 Aydemir'in çalışmasında 15. gazel olup “zer” şeklindedir.

38 Bkz., Tarlan, Fuzûlı̂ Dîvânı Şerhi, s. 221.
} 
18/1: $:^{39}$ Hatuñ reyhân-ı bûstân-ı cinândur

Kadüñ gül-deste-i gül-zâr-ı cândur

“Ayva tüylerin cennet bahçelerinin reyhânı (gibi), boyun (da) gönlün gül bahçesinin gül demeti (gibi)dir.

$\mathrm{Bu}$ beyit de bir önceki beyit gibi değerlendirilebilir. Tasavvufî olarak kesretin içinde vahdetin gizli oluşu ve insanın gönlünde kesrete olan zaafı, lirik bir yorum olarak da sevgilinin çeşitli benzetmelerle övülmesi şeklinde yorumlanabilir.

22/2: ${ }^{40}$ Bir elif kâmetlü bir ebrûsı nûna vir gönül

Anı sev ya'nî ki anuñ ân içinde ânı var

“Boyu elif (gibi düzgün ve) kaşı nûn (gibi olan bir sevgiliye) gönül ver. Onu sev, çünkü onun güzellik içinde güzelliği (câzibe içinde câzibesi) var."

Elif ve nûn yanyana gelince “ân” olarak okunabilir. Farsça “ân”, "güzellik, alım, câzibe" demektir. Elif kâmet, vahdettir. Bütün güzelliklerin kaynağı ve hakikî güzel, vâhid olan "Zât-1 İlâhî”dir.

22/6: Serv didüm kaddine $e^{41}$ bir gamz idüp dir gamzesi

Kankl servü̃̃ nâz u gunc u gonce-i handânı var

"Boyuna servi dedim, gamzesi bir işâret edip 'Hangi servinin naz ve cilveyle (açılan) gülen goncası (dudakları) var).' dedi.”

Dudağın vahdeti ifade ettiğine yukarıda değinilmişti. Boy ise zaten vahdetin sembolüdür ve genellikle serviye benzetilir. Fakat servi ne olursa olsun dünyevî ve maddî bir unsur olduğundan ilâhî vahdeti ifadede yetersiz kalacaktır. ${ }^{42}$

30/3: ${ }^{43}$ Benzedem mi serve anuñ kâmet-i dil-cûusını ${ }^{44}$

Servdür bir huşk u bî-endâm ${ }^{45}$ çûb-ı bî-tirâş

“Onun gönül çeken (câzibeli) boyunu serviye nasıl benzeteyim? (Onun boyuyla mukâyese edilince) servi (ancak) kuru ve biçimsiz, işlenmemiş bir tahta parçasıdır."

\footnotetext{
39 Vezni: mefâîlünx2/feûlün

40 Vezni: fâilâtünx3/fâilün. Aydemir'in çalışmasında 23. gazeldir.

41 Aydemir'in çalışmasında "kaddüñe" şeklindedir.

${ }^{42}$ Benzer bir yorum için bkz., Tarlan, Fuzûlî Dîvânı Şerhi, s. 57.

${ }^{43}$ Vezni: fâilâtünx3/fâilün

${ }^{44}$ Aydemir'in çalışmasında 31. gazel olup "dil-cûyını" şeklindedir.

45 Aydemir'in çalışmasında “...endâm u..." şeklindedir.
} 
$\mathrm{Bu}$ beyit de yukarıdaki beytin anlam çerçevesine girdiğinden üstteki açıklamalar bunun için de geçerlidir.

34/1: ${ }^{46}$ Iy yüzi gül boyı serv bûyı semen kûyı bâg

Şehr-i Medîne senüñ geştüñ içün bâg u râg

"Ey yüzü gül, boyu servi, kokusu yâsemin, semti bahçe (gibi yeşil ve çiçeklerle dolu olan) sevgili! Medîne şehri senin gezip dolaşman (seyretmen) için güllük gülistanlık (bir) bahçe olmuştur."

Bu gazel Hz. Peygamber için yazılmıştır. Rûşenî hüsn-i ta'lil sanatını kullandığı bu beyitte Medîne'nin özelliklerine sebep olarak Hz. Peygamber'i göstermiş ve Peygamberimizin yüceliğine işaret ederek onu övmüştür.

37/4: ${ }^{47}$ Görünür her âşıka her kadd ü haddi hûb u hoş

Cilve-i hüsn ü cemâl ü kâmet-i bâlâ-yı lşk

"Her âşığa, aşkın (muhabbetin zirve derecesinin) yüce endâmı (yüksekliği) ve güzellik cilveleri, (sevgilinin) boyu ve yanağı, (her şeyi) güzel görünür.”

$\mathrm{Bu}$ beyit ve gazelin tamamı, tasavvufî olarak yorumlanabileceği gibi dünyevi bir sevgiliye övgü olarak da düşünülmeye müsaittir. Beyitle ilgili şu yorumlar yapılabilir: Aşk, âşığa öyle bir duygu verir ki sevdiği varlıkta bir kusur görmez. Mâşûka ait her şey âşığa güzel görünür ve sevgilisini kimseyle mukâyese edilemeyecek yüce bir makama oturtur. Fakat mecâzî sevgililerde aşka sebebiyet veren özellikler geçici olduğundan, onlar için beslenen bu duygular da geçicidir. Hakikî sevgili olan Allah’1 bulanlar ise bu bakışı her zaman korurlar, çünkü onun kemâli daimîdir.

38/1: ${ }^{48} \quad$ Kaddüñe nice benzer serv-i sehîsi bâguñ

Bir meyvesiz agaçdur servisi bâg u râguñ

"Bağın fidan gibi düzgün servisi (senin) boyuna nasıl benzer? (Çünkü ne kadar güzel olsa da) bağın bahçenin servisi (nihâyetinde) meyvesiz bir ağaçtır.”

$\mathrm{Bu}$ beyit, 22 ve 30. gazellerden iktibas ettiğimiz beyitlere benzer başka bir örnektir. Dolayısıyla onlar için kaydettiklerimiz bu beyit için de geçerlidir. Fakat burada servinin meyvesiz olmasına değinilmesi bilhassa dikkati çekmektedir. Öyleyse sevgili

\footnotetext{
${ }^{46}$ Vezni: müfteilün/fâilün/ müfteilün/fâilün

${ }^{47}$ Vezni: fâilâtünx3/fâilün

${ }^{48}$ Vezni: müstef'ilün/faûlün/ müstef'ilün/faûlün
} 
meyve, yani mahsül sahibidir. Bu durumda âşık da nasiplenen konumunda olur. Böyle bir düşünce tasavvufî̀ yorumlara rahatlıkla kapı aralar. İlâhî kaynağa bağlanan insan, kesintisiz beslenme kaynağını bulmuş olarak sürekli mânevî vâridâtla gıdalanacaktır. Onun dışındaki varlıklar ise ne olursa olsun fânî unsurlardır ve sahip oldukları her şey aslen ilâhî kaynağa ait olup kendilerinden kaynaklanan bir varlıkları yoktur.

38/2: $\quad$ Sâyeñ ne yire salsañ biter nihâl-i izzet Iy serv-i sâye-perver başuma bas ayaguñ

“Gölgeni ne tarafa salsan yücelik (şeref) fidanı büyür. Ey gölgelendiren (himâyesi altına alan) servi! Ayağını başıma bas!”

Vahdeti ifade eden sevri için bu beyitte kullanılan "gölgelendirme" ifadesi bizi Allah'ın koruması yanında bir hükümdarın ya da beyin himâyesine de götürebilir. Bu bakımdan söz konusu beytin, Divan şiirindeki birçok beyit gibi birkaç şekilde anlamlandırılabileceğini söyleyebiliriz.

\section{7/2: ${ }^{49}$ Nice nisbet ideyin serve senüñ kâmetü̃̃i}

\section{Kâmetüñ kimi senüñ serv hoş-âyende degül}

"Senin boyunu serviye nasıl benzeteyim? (Çünkü) servi, senin boyun kadar hoşa gitmiyor (beğenilmiyor)."

Servi çok uzun ve endamlı bir ağaç olduğundan sevgilinin boyu için bir teşbih unsuru olarak kullanılır. Fakat şâirler bunu bir örnek kabîlinden kullanmakla birlikte, sevgilinin her anlamda benzersiz oluşunu da sıklıkla vurgularlar. Sevgili eşsizdir ve kimseye benzemeyen üstün vasıflarla muttasıftır. Bu anlamda onun boyuyla mukâyese edilince servi de sönük kalacaktır. Bu beytin de Allâh'ın benzersizliğini veya $\mathrm{Hz}$. Peygamber'in üstünlüklerini ifade ettiğini kabul etmek mümkündür.

\section{8/3: $:^{50}$ Sensin iy serv-i seĥे-sâye semen-sâ sünbülüm}

\section{Gül-ruhum bülbül zebânum gülşen-efrûzum menüm}

"Ey düzgün gölgeli (en doğru şekilde himâye eden) servi! Zülüfleri yâsemin kokulum, gül yanaklım, bülbül dillim (ve) gül bahçesini aydınlatan (ıșığım) benim.”

48. gazelin tamamına bakıldığında ilk algı olarak açık bir tasavvufî iz barındırmadığı akla gelmektedir. Fakat yukarıdaki bazı beyitlerde de işaret edildiği gibi,

\footnotetext{
${ }^{49}$ Vezni: feilâtünx3/feilün

${ }^{50}$ Vezni: fâilâtünx3/fâilün
} 
bu beyit de hem dünyevî hem de uhrevî bakış açılarıyla değerlendirilebilir. Söylenenleri tekrar etmeme adına burada beytin günümüz Türkçesinin verilmesiyle iktifâ edilmiştir. Yorumlar için yukarıdaki benzer beyitlere müracaat edilebilir.

49/1: ${ }^{51}$ Gitdi benden tâ kim ol serv-i hırâmânum menüm Aglamakdan doymadı bu çeşm-i giryânum menüm

"Benim o salına salına yürüyen servi boylu (sevgilim) gittiğinden beri, bu ağlayan gözlerim ağlamaya doymadı."

$\mathrm{Bu}$ gazelin tamamına bakıldığında tasavvufî̀ neşveyle yazıldığına dair işaretler bulunmaktadır. $\mathrm{Bu}$ beytin anlam çerçevesine bakıldığında da tasavvufta önemli hallerden olan "kabz" ve "bast”ın hatırlanması mümkündür. Buradan yola çıkıldığında şâirin, kalbinde mânevî esintileri yoğun olarak hissedemeyip kabz hâlinde bulunduğu bir sırada bu şiiri yazdığ düşünülebilir. ${ }^{52}$

56/4: ${ }^{53}$ Bitmesün serv-i sehî didüm görüp kaddin revân

Ne biter bir meyve virmez huşk u hod-rû çûbdan

“(Senin servi gibi) boyunla yürüyüşünü gördüğümde 'Düzgün (boylu) servi (boşuna) yeşermesin' (büyümesin diye düşündüm). Meyve vermeyen, kuru ve kendi kendine biten (yabânî) bir tahta parçasından ne yetişir (elde edilir)?’”

38. gazelin 1. beytinde de servinin meyvesiz oluşuna işaret edilmişti. Bu beyitte de sevgilin boyuyla mukâyese edilince servi, meyvesiz, kuru bir tahta parçasına benzetilmiştir. Bu beytin anlam çerçevesi 38/1 gibi değerlendirilebilir.

60/5: ${ }^{54}$ Gel oynayalum sarmaşı dolaşı çemende

Geh salınup iy serv-i revân bir sen ü bir men

"Ey yürüyen servi (gibi endamlı sevgilim)! Gel, sadece senle ben bazen nazlı nazlı yürüyerek çemende (yeşillik bahçede) sarmaş dolaş oynayalım.”

$\mathrm{Bu}$ gazelde açık bir tasavvufî anlam görünmemektedir. Dolayısıyla âşığın, mâşûkuna hislerini ve özlemini ifade ettiği bir şiir olarak değerlendirmek mümkündür. Fakat diğer taraftan, sâlikin tasavvufî temrînindeki halvet halleri ve sadece Rabbiyle

\footnotetext{
${ }^{51}$ Vezni: fâilâtünx3/fâilün

52 Kabz ve bast için bkz., Zafer Erginli vd., Metinlerle Tasavvuf Terimleri Sözlüğü, s. 506-513.

${ }^{53}$ Vezni: fâilâtünx3/fâilün

${ }^{54}$ Vezni: mef'ûlü/mefâîlüx2/ feûlün. Aydemir'in çalışmasında 62. gazeldir.
} 
başbaşa geçirdiği ibadet anlarının onda oluşturduğu coşku da bu beyti okurken rahatlıkla akla gelebilir.

77/1: ${ }^{55}$ Dir idüm gül yüzüñe olsa gülüñ gözi kaşı

Ya benefşe kohulu hattı kad-i serv-veşi

“Gülün gözü kaşı veyâ menekşe kokulu ayva tüyleri ve servi gibi boyu olsaydı (senin) yüzüne gül derdim.”

$\mathrm{Bu}$ gazelin diğer beyitlerindeki ifadelerden, bu şiirin Hz. Peygamber'e yazılmış olabileceği anlaşılmaktadır. Edebiyatımızda Hz. Peygamber'le özdeşleşen gül, bu beyitte onun yanında sönük kalışıyla kullanılmış ve Hz. Peygamber'in fizikî özellikleri ve endâmı övülmüştür.

77/7: Kadün üstinde gören haddüñi eydür ki görüñ

Salınur serv başı üstine alup güneşi

“Boyunun üstünde yanağını gören(ler): 'Bakın; servi, başının üstüne güneşi almış salınıyor.' der."

Aynı gazelin yedinci beyti, sanki Hz. Peygamber bir topluluğun karşısına çıkmış da tebliğ vazifesini yapıyormuş gibi bir tablo sunmaktadır. Burada onun yüzünün aydınlığına, yani nûruna ve insanlar içindeki yüce mevkiine işaret edildiği söylenebilir.

78/3: ${ }^{56}$ Resen-i zülfü̃ĩ dil tıflı salıncah düzedüp

Salınur bâg-ı cemâlüñde eyâ serv-i seĥ̂

“Ey düzgün boylu servi (gibi olan sevgilim)! Gönül çocuğu (çocuk gibi olan gönlüm), (senin) zülfünün ipini (saçının telini) salıncak yapıp güzel yüzünün bahçesinde sallaniyor."

Divan edebiyatında âşık sevgilinin saçına asılıdır. Zülfün her kıvrımında âşıkların biri sallanır. Tabii burada esasen salıncakta sallanma gibi bir manzara olmaz, daha çok bir çengele asılmış insanlar hayal edilir. Fakat âşık zaten mâşûkun eziyetinden zevk alır. ${ }^{57}$ Bu beyitte de böyle bir zevk hâli görülmektedir. Buradan, asıl sevgili olan Allâh'ın yolunda çekilen sıkıntılardan şikâyetçi olmamak gerektiği gibi bir yoruma gitmek mümkündür.

\footnotetext{
${ }^{55}$ Vezni: feilâtünx3/feilün

${ }^{56}$ Vezni: feilâtünx3/feilün

${ }^{57}$ Bkz: İskender Pala, Ansiklopedik Dîvan Şiiri Sözlüğü, Kapı Yayınları, İstanbul 2004, s. 37. "Saç" için bkz: a.e, s. 384-385.
} 


\section{2/2: ${ }^{58}$ Benefşe hattuñuñ bûyından olup bûstân gönlüm}

Sehî servüñ klyâmından revânum bâg u râg oldı

“Gönlüm menekşe (kokulu) ayva tüylerinin kokusundan güzel kokulu çiçeklerle dolu (bir) bahçe olup rûhum (da) fidan gibi düzgün servi boyunun ayağa kalkmasıyla güllük gülistanlık (bir) bahçeye dönüştü (şenlendi).”

"Revân” kelimesi çok anlamlı sözcüklerden olup bir anlamı da "ruh, can”dır ve yukarıdaki beyitte bu anlamıyla kullanıldığı anlaşılmaktadır. Âşık sevgiliyi görünce kendinden geçer, dünyası aydınlanır. Bu beyitte de sevgilinin kendisini göstermesiyle âşık mutluluğa gark olmuştur.

83/6: $:^{59}$ Boyuña serv dir idüm servü̃̃̃ olsa Semen-sâ sünbül $\ddot{u ̈}^{60}$ gülden yanagl

"Servinin yasemin kokulu saçı ve gülden yanağı olsaydı (senin) boyuna servi derdim."

Bu beyitte 77/1'de gülle yapılan mukâyeseye benzer bir kullanım görülmektedir. Sevgilinin boyu serviyle mukâyese edilemez, çünkü servi onun yanında sönük kalmaktadır. Bu beytin yorumu için 47/2'deki açıklamalara müracaat edilebilir.

\section{Sonuç}

Bu incelemede, 15. yüzyılın önemli mutasavvıf şâirlerinden Dede Ömer-i Rûşenî Dîvânında “boy”un sevgiliye âit bir unsur olarak kullanılışına dair şu sonuçlara ulaşılmıştır:

Sevgilinin boyu genellikle serviye benzetilmiştir. Servi Dîvân şiirinde "vahdet"i ifade eden "boy" için sıklıkla kullanılan bir teşbih unsurudur. Fakat bazı beyitlerde servi bir teşbih unsurundan ziyade, bir mukâyese unsuru olarak kullanılarak sevgilinin üstünlüğüne ve benzersizliğine dikkat çekilmiştir.

Rûşenî’nin bu çalışmada faydalanılan beyitlerinin ikisi na't türünde bir kasîdesine ait olup diğer yirmi altı tanesi gazellerinden alınmıştır. Bu beyitlerin büyük kısmı dinî ve tasavvufî neşveyle yazılmış şiirlere ait olmakla birlikte, açık bir mânevî anlam barındırmayan beyitlere de rastlanmaktadır. $\mathrm{Bu}$ tür beyitlerde boy için yine klâsik

\footnotetext{
${ }^{58}$ Vezni: mefâîlünx4

${ }^{59}$ Vezni: mefâillünx2/ feûlün

${ }^{60}$ Tavukçu'nun çalışmasında “sünbüli” şeklindedir.
} 
benzetme unsurları olan servi, şimşâd gibi kelimeler kullanılsa da ön planda mecâzî güzelin övüldüğü hissedilmektedir.

Sevgilinin boyu için teşbih ya da mukâyese unsuru olarak kullanılan "şimşad"la ilgili olarak bir noktaya dikkati çekmek gerekmektedir. Şimşâd da servi gibi bir ağaç olmasına rağmen, servi gibi "vahdet"i değil, "kesret"i sembolize eder. Bu sebeple onun kullanıldığı yerlerde, seyr ü sülûkunda sâlikin takılıp kalabileceği, yani Allah’a ulaşma yolunda ona engel oluşturabilecek olan imtihan unsurları hatırlanmaktadır. Kâinattaki her şey Allah'ın isim ve sıfatlarının tecellilerinden ibaret olmakla birlikte, insandan beklenen tavır, bunların hiçbirini kalbinin merkezine oturtmayıp yegâne bâkî ve hakikî sevgili olan Allah'ta fânî olarak sonsuzluğa ermesidir. Rûşenî'nin vahdet-kesret çağrışımı olan şiirlerinde de bu anlamlar mevcuttur.

Sonuç olarak; Rûşenî Dîvân’ında “boy”, zengin çağrışım imkânlarıyla kullanılmış olmakla birlikte, ağırlıklı muhtevâ dinî ve tasavvufî yorumlara oldukça müsait olarak "vahdet" ve "zât-1 ilâhî" anlamları etrafinda şekillenmiştir. 


\section{Kaynakça}

Altuntop, Nurten, “Dede Ömer Rûşenî’nin Dîvânı'nda Tasavvuf”, Yüksek Lisans Tezi, Hitit Üniversitesi Sosyal Bilimler Enstitüsü, Çorum 2015.

Baş, Münire Kevser, "RÛŞENÎ, Dede Ömer", Türk Edebiyatı İsimler Sözlüğü, http://www.turkedebiyatiisimlersozlugu.com/index.php?sayfa=detay\&detay=6302, E.T: 04, 11, 2015

Canan, İbrahim, Kütüb-i Sitte Muhtasarı Tercüme ve Şerhi, C. 9, Akçağ Yayınları, Ankara 1990.

Erginli, Zafer vd., Metinlerle Tasavvuf Terimleri Sözlü̆̆̈̈, Kalem Yayınevi, İstanbul 2006.

Mûsâbeyli, Âzâde, Dede Ömer Rûşenî ve Külliyâtı, Kafkaz Üni. Kafkaz Araştırmaları Enstitüsü, 2014.

Onay, Ahmet Talât, Açıklamalı Dîvân Şiiri Sözlüğü (haz. Cemal Kurnaz), Birleşik Yayınevi, Ankara 2007.

Pala, İskender, Ansiklopedik Dîvan Şiiri Sözlüğ̈̈, Kap1 Yayınları, İstanbul 2004.

Seccâdî, Seyyid Ca'fer, Tasavvuf ve Irfan Terimleri Sözlüğü (çev. Hakkı Uygur), Ensar Neşriyat, İstanbul 2007.

Semra Aydemir, "Dede Ömer Rûşenî (Hayatı, Eserleri ve Dîvânının Tenkidli Metni)" Yüksek Lisans Tezi, Selçuk Üniversitesi Sosyal Bilimler Enstitüsü, Konya 1990.

Tarlan, Ali Nihat, Fuzûlî Dîvânı Şerhi, Akçağ Yayınları, Ankara 1998.

Tavukçu, Orhan Kemal, Dede Ömer Rûşenî Hayatı, Eserleri, Edebî Kişiliği ve Dîvânının Tenkidli Metni, http://ekitap.kulturturizm.gov.tr/Eklenti/10601,dede-omerrusenipdf.pdf?0 E.T: 07.04.1015.

Uzun, Mustafa, "Dede Ömer Rûşenî”, DİA, C.9, s. 81-83. 